九州大学学術情報リポジトリ

Kyushu University Institutional Repository

\title{
An Analysis of the Determinants Influencing Store Choice by Co-op Members Towards Consumer Cooperatives when Purchasing Rice in Japan
}

LIU, Ran

Laboratory of Food Marketing and Distribution, Division of Agricultural and Resource Economics, Department of Agricultural and Resource Economics, Faculty of Agriculture, Kyushu University

\section{MORITAKA, Masahiro}

Laboratory of Food Marketing and Distribution, Division of Agricultural and Resource

Economics, Department of Agricultural and Resource Economics, Faculty of Agriculture, Kyushu University

FUKUDA, Susumu

Laboratory of Food Marketing and Distribution, Division of Agricultural and Resource

Economics, Department of Agricultural and Resource Economics, Faculty of Agriculture, Kyushu University

https://doi.org/10.5109/2339031

出版情報: 九州大学大学院農学研究院紀要. 64 (2)，pp.379-386，2019-09-02. Faculty of Agriculture, Kyushu University

バージョン：

権利関係: 


\title{
An Analysis of the Determinants Influencing Store Choice by Co-op Members Towards Consumer Cooperatives when Purchasing Rice in Japan
}

\author{
Ran LIU, Masahiro MORITAKA and Susumu FUKUDA* \\ Laboratory of Food Marketing and Distribution, Division of Agricultural and Resource Economics, \\ Department of Agricultural and Resource Economics, Faculty of Agriculture, \\ Kyushu University, Fukuoka, 819-0395, Japan \\ (Received May 7, 2019 and accepted May 8, 2019)
}

\begin{abstract}
From the view point of rice consumption expansion in Japan, toward the specific rice retail market in domestic where relatively large demand still exists, it is necessary to consider the development of marketing strategies to improve the consumption of the consumers in that specific market. Consumer cooperatives (hereinafter referred to as "co-ops") are an expected retail market. However, under the increased competition with other formats in the shrinking domestic rice market, the use frequency of co-ops by co-op members has consistently decreased over the past decade, meanwhile, their frequency of supermarket use has continued to rise. Furthermore, by 2015, the frequency of co-op use had already been equaled or exceeded by supermarkets, even when purchasing rice which was being recognized as the strategic commodity item. Therefore, the objective of this paper is to find out the causal factors as the determinants influencing the store choice by co-op members towards co-ops when purchasing rice by running a specified binomial logit regression model based and reviewing on the analysis results by Liu et al. (2017). As well, revealing whether any changes occurred in the determinants during the past several years by comparing the situation of 2015 with 2006 in order to provide some recommendations for present co-ops' rice retailing business is additional purpose of this paper.
\end{abstract}

Key words: consumer cooperatives (co-ops), rice consumption expansion, store choice, binomial logistic regression

\section{INTRODUCTION}

In recent years, Japan's food self-sufficiency rate has been the lowest among the major developed countries as posted by Japan Agricultural News. Japan's Ministry of Agriculture, Forestry and Fisheries (hereinafter referred to as "MAFF") indicated that the decline of the domestic rice market was one of the main causes for this low rate. To promote food security relying on the improvement of food self-sufficiency rate, working towards measures to expand the consumption of rice, the only food that can be self-sufficient in Japan, appears to be both important and necessary (MAFF, 2008)

When considering the rice consumption expansion, if putting the point of view on the domestic market, a saturated market for rice, it has to be admitted that market size is shrinking. However, as Fuyuki (2005) stated, rice, as the most typical and traditional staple food in Japan, will not disappear at all or turn into extremely small-sized in this country. Even though due to the characteristics of as staple foods and basic crops, rice is gradually weakened and diluted with economic development, and would continue to weaken in the future (Kako, 2003), it is still and will be continually recognized as the largest source of calories for the Japanese national, therefore it certainly has a certain demand even in the far future. Fuyuki (2005) also pointed out that the general product life-cycle often used when considering market strategies for industrial products is not applicable in the case of the rice market. Rice, at least in

\footnotetext{
* Corresponding author (E-mail: sufukuda@agr.kyushu-u.ac.jp)
}

Japan, does not have the nature that will be completely replaced by other products even in the period of decline in life-cycle. Therefore, toward the specific rice retail market in domestic where relatively large demand still exists, it is necessary to consider the development of marketing strategies to improve the consumption of the consumers in that specific market.

Mentioning a specific rice retail market, as stated in author's published research paper previously, Liu et al. (2017), the Japanese Consumer Cooperative (hereinafter referred to as "CO-OP Japan") is generally an expected retail format because it is the largest retail group in Japan based on cooperative philosophies and democratic management principles, the aim of which is to contribute to the creation of a consumer-oriented social system centered on ensuring food safety (Kikuchi and Yamao, 2014). As reported by the Japan Finance Corporation (2011), consumers' food safety concerns and health intentions have both risen drastically since the Great East Japan Earthquake. With respect to this point especially, CO-OP Japan has already developed a number of unique characteristics and operation methods, including home delivery and group buying systems to provide fresher, healthier products to co-op members owing to reduced shopping time, additionally sanchoku, a specific type of community-supported agriculture philosophy originally developed by CO-OP Japan to ensure a consistent supply of safe and high quality products in response to consumers' food safety demands (Liu et al., 2017). Based on the performance of CO-OP Japan, recognizing this consumer-oriented social system holding the food (of course, including rice) retail function to be as the targeted specific rice retail market, is reasonable. 
Meanwhile, improving existing co-op members' use frequency of CO-OP Japan could also be expected to be an effective approach for promoting the expansion of rice consumption.

Liu et al. (2017) pointed out that, under the background of the increased competition based on the marketing strategies connected to food safety concerns for capturing consumers between co-ops and other retail formats such as supermarkets, among all CO-OP Japan members, the aggregate proportion of those who rarely use co-ops (monthly spending in co-ops lower than $10,000 \mathrm{JPY}$ ) increased from $28.4 \%$ in 2006 to $46.2 \%$ in 2015. It is quite clear that the frequency of co-op use by members has consistently decreased over the past decade, meanwhile, their frequency of supermarket use has continued to rise (Liu et al., 2017). Furthermore, as reported by the JCCU (2015), in 2012, co-ops were still being the most frequently used rice retail format for coop members; however, by 2015, the frequency of co-op use had already been equaled or exceeded by supermarkets, even when purchasing rice. In addition, by reviewing the co-op members' survey results (JCCU, 2006; JCCU, 2012), Liu et al. (2017) also suggested that some changes have probably occurred in members' leading reasons for choosing their favorite rice retail format.

Accordingly, there is a reason to wonder that what currently the determining factors influencing the members' store choice towards co-ops when purchasing rice are. And how to formulate more effective marketing strategies for increasing existing members' use frequency of co-op when purchasing rice is still a question not yet being answered clearly.

\section{LITERATURE REVIEW AND OBJECTIVES}

Mainly in a review of the objective-related literature, Liu et al. (2017), conducted by author previously, it focused on figuring out the relative position of co-ops among the numerous current rice retail formats, on the basis of STP (segmentation, targeting, positioning) theory, starting from the identification of co-op members' diversified rice-purchasing needs, regarding the Fukuoka Prefectural Consumer Cooperative (hereinafter referred to as "F-Co-op" ) as the investigation object, through an approach that compares two different time periods, 2006 and 2015, when conducting F-Co-op members' surveys, 2006 and 2015. The findings of Liu et al. (2017) indicated that there are six kinds of rice-purchasing needs among F-co-op members. Furthermore, based on these needs, members can be divided into five segments based on rice purchasing behavior: "Promotional information seekers", "Trustworthiness seekers", "Low price seekers", "Members with low involvement in rice purchases", and "Non-price elements seekers". Moreover, among these segments, "Promotional information seekers" and "Non-price elements seekers" were found to maintain a high level of loyalty to co-ops when purchasing rice, and "Trustworthiness seekers" were recognized as a new segment that prefers to be loyal to co-ops (Liu et al., 2017). With respect to the characteristics of above-mentioned three co-op member segments, "Promotional information seekers" ("PI seekers"), "Non-price elements seekers" ("NE seekers") and "Trustworthiness seekers" ("TW seekers"), which are proved royal to co-ops, including each segment's relationship with those rice-purchasing needs, here Table 1 can show the summarizing about the findings more clearly. Accordingly, co-ops are recognized and believed by loyal members to be in a position to satisfy all of their rice purchasing needs except for "Low price need" (Liu et al., 2017).

Table 1. Characteristics of those three co-op member

\begin{tabular}{|c|c|c|c|}
\hline \multirow{2}{*}{ Segments royal to co-ops } & \multicolumn{2}{|c|}{ Composition ratio } & \multirow{2}{*}{ - High-related rice-purchasing need(s) } \\
\hline & 2006 & 2015 & \\
\hline \multirow{3}{*}{ PI seekers } & \multirow{3}{*}{$31.67 \%$} & \multirow{3}{*}{$31.29 \%$} & Promotional information need \\
\hline & & & Trustworthiness need \\
\hline & & & Rinse-free need \\
\hline \multirow{4}{*}{ NE seekers } & \multirow{4}{*}{$8.48 \%$} & \multirow{4}{*}{$9.71 \%$} & Official information need \\
\hline & & & Trustworthiness need \\
\hline & & & Rice milling date need \\
\hline & & & Rinse-free need \\
\hline TW seekers & $9.09 \%$ & $18.55 \%$ & Trustworthiness need \\
\hline
\end{tabular}

Source: Table 6. and Fig. 1. in Liu et al.(2017)

As reviewed above, regarding Liu et al. (2017), it can be seen that as one rice retail format, the position of co-ops among the numerous formats has been figured out, however, how to feedback to the original question: what are currently the determining factors influencing the members' store choice of co-ops when purchasing rice, is still a problem. Therefore, the objective of the present paper is to find out the causal factors to be as the determinants for increasing the use frequency, from the above-mentioned six rice-purchasing needs identified by Liu et al. (2017) and also from the elements about socio-demographic profiles and rice purchasing behaviors of co-op members. As well, revealing whether any changes occurred in the determinants during the past several years by comparing the situation of 2015 with 2006 in order to provide some recommendations for present co-ops' rice retailing business is additional purpose of this paper.

\section{METHODOLOGY AND DATA}

\section{Methodology}

In order to analyze the dichotomous decision of $\mathrm{co}-$ op members (consumers) on whether or not to use coops when purchasing rice, an appropriate econometric tool is a binomial logit regression model based on discrete choice theory (Kim and Yoon, 2004; Resano et al., 2011). As Kim and Yoon (2004) stated, "discrete choice theory is the study of behavior in situations where decision makers must select from a finite set of alternatives.

\footnotetext{
${ }^{1}$ Regarding the detailed introduction of "F-Co-op", please refer to the subsequent chapter "Introduction of investigation object" of the chapter 2 "LITERATURE REVIEW AND OBJECTIVES" in Liu et al. (2017).
} 
It posits that an individual is likely to choose an alternative over others when the level of its utility to him is greater than the utility of other alternative"; "this discrete choice model can also be applied to the issue of customer loyalty". The canonical discrete choice model specifies the probability of an individual to choose a certain alternative as a function of observed attributes of the individual and of the alternatives available to him, and these attributes are supposed to be causal variables affecting the choice (Cosslett, 1981). For the objective of this paper, the set of alternatives is "to use co-op" and "not to use co-op". By reference to Kim and Yoon (2004), the factors that determinately influence the decision of an existing co-op member on whether to choose co-ops as his rice purchase store are divided into choice-specific factors (rice-purchasing needs) such as the need of promotional information or of trustworthiness, and individual-specific factors (socio-demographic characteristics and rice purchase behavioral characteristics) such as household income, age or actual rice purchase price.

Therefore, to accomplish the objective of this paper, a binomial logit regression model as below was specified and estimated. There are two equations (1) and (2) combined in this estimation model which assumes an underlying response variable $\mathrm{Y}$, logit of the probability to make the store choice towards co-ops when purchasing rice $(S C C O)$, defined as follows:

$$
\begin{array}{r}
\mathrm{Y}=\log _{\mathrm{e}}\left(\frac{\mathrm{P}_{\mathrm{j}=1}}{1-\mathrm{P}_{\mathrm{j}=1}}\right)=\alpha+\gamma \mathrm{D}_{\mathrm{t}}+\sum \beta_{2006 \mathrm{~m}} \mathrm{X}_{\mathrm{m}} \\
+\sum \mathrm{\delta}_{\mathrm{m}}\left(\mathrm{D}_{\mathrm{t}} \mathrm{X}_{\mathrm{m}}\right) \\
\beta_{2015 \mathrm{~m}}=\delta_{\mathrm{m}}+\beta_{2006 \mathrm{~m}}
\end{array}
$$

where $\boldsymbol{\gamma}, \delta_{\mathrm{m}}, \boldsymbol{\beta}_{2006 \mathrm{~m}}$ and $\boldsymbol{\beta}_{2015 \mathrm{~m}}$ are vector of parameters to be estimated. Co-op members' original scores (1: frequently using co-ops, 2: occasionally using co-ops and 3 : never using co-ops) of their use frequency of co-ops when purchasing rice have been converted into a dummy variable $\mathrm{j}$, which accounts if the consumer's original score is 2 or 3 then setting $j=0$ in equation (1). $X_{m}$ is the $\mathrm{m}^{\text {th }}$ independent explanatory variable, potential factors that may be determinants, as shown in Table 3. Since it was hypothesized that some changes might have occurred in the determinants during the past several years, for estimating that, $D_{t}$, a dummy variable of the specific years when conducting the twice surveys of $\mathrm{F}-$ co-op members, defining 2015 coding as 1 , is set into the model. Relating to $D_{t}, \gamma$ is the vector of coefficient when $\mathrm{D}_{\mathrm{t}}$ contributes for the model as a constant dummy. On the other hand, an interaction term combining $\mathrm{D}_{\mathrm{t}}$ with $\mathrm{X}_{\mathrm{m}}$ is introduced to this model for testing $\delta_{m}$, the vector of coefficients associated with the interaction term, which represents the change value of the specified coefficient of each explanatory variable up to 2015 if referenced to 2006. Then based on equation (2), adding $\delta_{m}$ to $\beta_{2006 m}$, the specified coefficient of each explanatory variable of 2006 , to calculate the value of $2015, \beta_{2015 \mathrm{~m}}$. Through this method, the comparison on determinants between two years can be estimated at once.

\section{Data}

The primary data used for this objective were totally same with those of Liu et al. (2017), collected twice between February and March in 2006 and 2015 using nearly identical structured mail questionnaire surveys. Referring to Liu et al. (2017), "The respondents were FCo-op members living in the vicinity of four areas that cover all of Fukuoka Prefecture. Both of the questionnaires included three parts: a socio-demographic profile, rice purchasing behavior, and psychographic criteria. After excluding those with incomplete information, a two-stage random sampling procedure was conducted to select 1,320 effective samples for analysis from a total of 1,473 respondents in 2006 and 1,617 effective samples from a total of 1,689 respondents in 2015". The sociodemographic variables include "place of residence", "age", "gender", "annual household income" and "family size". The variables of rice purchasing behavior include "number of fixed rice purchase stores", "fixed production place(s) or brand(s)", "actual purchase price range" and "retail formats frequently / occasionally used". 16 effective psychographic criteria ${ }^{4}$, taken as manifestations of members' wants when purchasing rice, were utilized in the questionnaire.

As above-stated, for the objective of this paper, the factors that might determinately influence the decision of an existing co-op member on whether to choose coops as his rice purchase store are introduced to the binomial logit regression model as the independent variables. In addition to socio-demographic and rice purchase behavioral variables, co-op members' choice-specific factors: six kinds of rice-purchasing needs identified in Liu et al. (2017), are independent explanatory variables as well. For proving a clear introduction on the meaning and structure of those 6 rice-purchasing needs, an analysis result table appeared once in Liu et al. (2017) needs to be cited here, and presented as Table 2. Three needs were extracted by the exploratory factor analysis (EFA) taking 13 of those 16 psychographic criteria as independent variables: "Official information need", "Trustworthiness need", "Promotional information need". Other than that, "Low price need", "Rinse-free needs", and "Rice milling date need" were independently handled as three single rice-purchasing needs of members.

Accordingly, Table 3 provides a summary of all the

\footnotetext{
2 Regarding the descriptive statistical results including the result comparison between 2006 and 2015 of the socio-demographic variables, please refer to Table 1 in Liu et al. (2017).

Regarding the descriptive statistical results including the result comparison between 2006 and 2015 of the rice purchasing behavior variables, please refer to Table 2 in Liu et al. (2017).

${ }^{4}$ Each criterion was ranked on a 5-point Likert scale from " $1=$ not important at all" to " $5=$ very important".
} 
variables including both dependent and independent explanatory variables used in the binomial logit regression model.

\section{RESULTS AND DISCUSSION}

Table 4 presents the estimation results of the binomial logit model that explains the determinants influencing the existing co-op members' store choice towards co-ops when purchasing rice.

In the final model, several specific variables, "gender $(G E N)$ ", "family size (FS1 6)", "tendency to purchase rice in fixed store(s) (TdFS)", "tendency to require rice with fixed production place(s) or brand(s) (TdFP/B)" and "actual purchase price range $(P)$ ", listed originally in Table 3, were excluded from the explanatory variables. As for the reasons for exclusion, about gender, from the male and female ratio of respondents in the two surveys, females tend to be overwhelmingly remaining over 90\% in any year would extremely impact on regression analysis in a bad way, so it was excluded. Regarding family size, after confirming the correlation coefficient with all other variables, it was suggested that a quite high correlation with "age" remaining 0.520 exists so that there is a suspicion that multiple collinearity will appear when entering family size into the regression model simultaneously with age, therefore it was deleted. Next, because there is similarity in meaning with "store choice towards co-ops", which is just the dependent variable of this objective, the variable of the trend to purchase rice in fixed store(s) was finally considered to be unused. The presence or absence of a fixed tendency of rice production place(s) and brand(s) was removed because it is difficult to interpret the associated analyzed result. The phenomenon of multiple collinearity happened between "actual purchase price range" and "low price need" when

Table 2. Rice-purchasing needs of co-op members (EFA result)

\begin{tabular}{|c|c|c|c|c|}
\hline \multirow[b]{2}{*}{ Psychographic criteria } & \multicolumn{3}{|c|}{ Rotated factor loading } & \multirow{2}{*}{ Communality } \\
\hline & Factor1 & Factor2 & Factor3 & \\
\hline Rice variety & $\underline{0.775}$ & 0.229 & 0.099 & .663 \\
\hline Production place & $\underline{0.675}$ & 0.222 & 0.060 & .508 \\
\hline Brand & $\underline{0.669}$ & 0.105 & 0.130 & .475 \\
\hline Single species & $\underline{0.406}$ & 0.325 & 0.026 & .271 \\
\hline Production year & $\underline{0.399}$ & $\underline{0.382}$ & 0.031 & .307 \\
\hline Faith in purchase store & 0.139 & $\underline{0.625}$ & 0.016 & .410 \\
\hline Cultivation history information disclosure & 0.169 & $\underline{0.577}$ & 0.198 & .400 \\
\hline Reputation from other buyers & 0.157 & $\underline{0.520}$ & 0.219 & .344 \\
\hline Specially cultivated rice & 0.131 & $\underline{0.501}$ & 0.105 & .279 \\
\hline Good taste & 0.248 & $\underline{0.473}$ & 0.069 & .290 \\
\hline Advertising words on the package & 0.058 & 0.127 & $\underline{0.830}$ & .708 \\
\hline Design of packaging & 0.079 & 0.059 & $\underline{0.714}$ & .519 \\
\hline Advertisement and promotion & 0.100 & 0.210 & $\underline{0.637}$ & .460 \\
\hline Low price (single as Factor4) & & & & lower than 0.1 \\
\hline Rinse-free (single as Factor5) & & & & lower than 0.1 \\
\hline Rice milling date (single as Factor6) & & & & higher than 0.9 \\
\hline Rotation sums of squared loadings & 4.061 & 1.833 & 1.309 & 7.203 \\
\hline Cumulative \% of variance & 31.235 & 45.337 & 55.409 & \\
\hline Cronbach's a & 0.769 & 0.713 & 0.781 & \\
\hline
\end{tabular}

Source: Table 4. in Liu et al. (2017)

Note: (1) "_ " is for highlighting the factor loadings that are higher than 0.380 .

(2) The EFA was conducted with the maximum likelihood (ML) method of extraction with varimax rotation. 
Table 3. Description of the variables used in the binomial logit regression model

\begin{tabular}{|c|c|c|c|}
\hline \multicolumn{4}{|c|}{ Dependent Variable } \\
\hline Variables & Measurement & Abbreviation & Description \\
\hline Store choice towards co-ops & Dummy & scco & $\begin{array}{c}\text { "Frequently using co-ops" }=1 \\
\text { "Never using co-ops" \& "Occasionally using co-op" }=0\end{array}$ \\
\hline \multicolumn{4}{|c|}{ Indenpendent Variable } \\
\hline Variables & Measurement & Abbreviation & Description \\
\hline Year & Dummy & $T$ & $" 2015 "=1 ; " 2006 "=0$ \\
\hline \multirow{4}{*}{ Place of residence } & $\begin{array}{l}\text { Dummy of } \\
\text { Keichiku / Tagawa }\end{array}$ & $\operatorname{KeT} T a$ & "Vicinity of Keichiku / Tagawa"=1; Other categories=0 \\
\hline & $\begin{array}{l}\text { Dummy of } \\
\text { Kitakyushu city } \\
\end{array}$ & $K K$ & "Vicinity of Kitakyushu city"=1; Other categories $=0$ \\
\hline & \begin{tabular}{|l|} 
Dummy of \\
Kurume city \\
\end{tabular} & $K R M$ & "Vicinity of Kurume city"=1; Other categories $=0$ \\
\hline & Fukuoka city & FUK & (Reference category) \\
\hline Gender & Dummy & GEN & "Female" $=1$; "Male" $=0$ \\
\hline Age & Scale data & $A G E$ & Being used as a proportional scale by taking the class value \\
\hline Annual household income & Dummy & AHI & " $\geq 6$ million JYP" $=1 ; "<6$ million JYP" $=0$ \\
\hline \multirow{6}{*}{ Family size } & Dummy of 1 person & FSI & "1family member"=1; Other categories $=0$ \\
\hline & 2 persons & $F S 2$ & (Reference category) \\
\hline & Dummy of 3 persons & FS3 & "3 family members"=1; Other categories $=0$ \\
\hline & Dummy of 4 persons & FS4 & "4 family members"=1; Other categories $=0$ \\
\hline & Dummy of 5 persons & FS5 & "5 family members"=1; Other categories $=0$ \\
\hline & \begin{tabular}{|l|} 
Dummy of $\geq 6$ \\
persons
\end{tabular} & FS6 & $" \geq 6$ family members" $=1$; Other categories $=0$ \\
\hline $\begin{array}{l}\text { Tendency to purchase rice in fixed } \\
\text { store(s) }\end{array}$ & Dummy & $T d F S$ & Yes $=1 ;$ No $=0$ \\
\hline $\begin{array}{l}\text { Tendency to require rice with fixed } \\
\text { production place (s) or brand(s) }\end{array}$ & Dummy & $T d F P / B$ & Yes $=1 ; N_{0}=0$ \\
\hline $\begin{array}{l}\text { Co-ops handle the rice with the } \\
\text { required production place(s) or } \\
\text { brand(s) }\end{array}$ & Dummy & $\operatorname{CoR}$ & Yes $=1 ; N_{0}=0$ \\
\hline $\begin{array}{l}\text { Freely gaining rice from family or } \\
\text { relatives }\end{array}$ & Dummy & $F a / R c R$ & Yes $=1 ; N_{0}=0$ \\
\hline Purchasing from rice farmers directly & Dummy & FarR & Yes $=1 ; \mathrm{No}=0$ \\
\hline Actual purchase price range & Scale data & $P$ & Being used as a proportional scale by taking the class value \\
\hline Low price needs & Scale data & $L P$ & Z-score of the evaluation score of criterion "Low price" \\
\hline Rice milling date need & Scale data & $R M D$ & Z-score of the evaluation score of criterion "Rice milling date" \\
\hline Rinse-free need & Scale data & Rf & Z-score of the evaluation score of criterion "Rinse-free" \\
\hline Official information need & Scale data & Offinfo & Factor score of factor 1 calculated by EFA \\
\hline Trustworthiness need & Scale data & $T W$ & Factor score of factor 2 calculated by EFA \\
\hline Promotional information need & Scale data & Promunfo & Factor score of factor 3 calculated by EFA \\
\hline
\end{tabular}

Source: (1) The surveys on rice purchase behavior and attitude of F-Coop members conducted separately in 2006 and 2015.

(2) The result of EFA showed in Table 2.

using both of them in regression, so the actual price was excluded from the analysis model.

As a result of estimating the model after considering each variable's applicability prudentially, the P-value of the Omnibus Test is statistically significant at the level of $1 \%$, that means no problem in adopting this model (Table 4). In addition, the pseudo coefficient of determination (Nagelkerke $\mathrm{R}$ squared) as the fitness index of the model is 0.487 , represents fitness is good (Table 4).

With respect to the estimation results of the determinants influencing the existing co-op members' store choice towards co-ops when purchasing rice, they are going to be divided into positive determinants and negative ones for interpreting.

As shown in Table 4, firstly, it was tested there is a significant tendency that if the required rice production place(s) or brand(s) was handled by the co-ops (CoR), co-op members would tend to choose co-ops as their rice purchase store more possibly. Next, the results sug- gested that for co-op members, the more they pay attention to and seek for "trustworthiness need (TW)", "rinse-free need $(R F)$ " and "official information need (OffiInfo)" when purchasing rice, the more tendency they have to prefer to use co-ops than other retail formats. In addition, the, the coefficient associated with the change value of the specified coefficient of each explanatory variable up to 2015 if referenced to 2006 , indicated that it of "official information need (OffiInfo)" presents a significant result at $5 \%$ which means this factor is a relatively new determinant with the influence on members' choice towards co-ops became stronger during past 10 years. Next, co-op members who have relatively high household income $(A H I)$ tend to use the coop more frequently, and this point became statistically prominent 10 years after 2006. Lastly, it can be said according to the result that as the age $(A G E)$ increases, the frequency of use of co-ops tends to be higher.

On the other hand, regarding the negative determi- 
nants, there are "freely gaining rice from family or relatives (Fa/ReR)" and "purchasing from rice farmers directly (FarR)" estimated out by our model. Additionally, with regard to the vicinity of Keichiku / Tagawa (KeTa), in the case of 2006, co-op members in that area tended not to use the co-op obviously, however by 2015 , almost no negative influence was seen. This is considered to be due to the fact that along with co-ops' business development such as delivery service even covering the mountainous area like the vicinity of Keichiku / Tagawa, the use frequency of co-ops has become considerably high in recent years.

\section{CONCLUSION}

This paper, with a brush-up analysis in a binomial logit regression model reviewed on author's previous paper Liu et al. (2017), estimated out the causal factors to be as the determinants for increasing the members' use frequency of co-ops when purchasing rice. Moreover, it revealed the prominent changes occurred in the determinants during the past several years, as the results explained in the session above. According to these findings, consequently, some recommendations for improving co-ops' rice retailing business in marketing strategies in order to promote members choose co-ops as for their rice purchase more frequently and generally can be offered. As stated in Liu et al. (2017), "In order to obtain some recommendations for advancing more effective rice retail strategies, what kind of manifestations of F-Co-op members' wants are highly valued by each of these three segments compared with 2006 needs to be clarified. The manifestations of wants were presented through the criteria that influence each of the needs identified in the EFA results" (Table 2). The test (T-test) to estimate the highly valued manifestations of co-op members' wants ${ }^{5}$ has been conducted in Liu et al. (2017). Presently, combining with the new analysis results about determinants of this paper, the brush-up interpretation of the recommendations to promote more effective rice retail strategies will be mainly stated.

To provide persuasive evidence more clearly for the interpretation as follows, a table presented once in Liu et al. (2017) for showing the results of the test above-mentioned needs to be cited here, and utilized as well with brush-up information as Table 5. As for more effectively targeting each of the three segments loyal to co-ops, to pay more attention to and to satisfy the needs determining store choice towards co-ops ("trustworthiness need", "rinse-free need" and "official information need") of members belonging to each royal segment, in accordance with the marketing theory, is absolutely necessary and extremely important.

With reference to Table 5 , it can be seen that no matter for which segment, "trustworthiness need" is always being there influencing members' choice deci-

Table 4. Estimation results of binomial logit regression

\begin{tabular}{|c|c|c|c|c|c|c|c|}
\hline Variables & $\begin{array}{c}\text { Coefficient } \\
(\mathrm{a} / \mathrm{Y})\end{array}$ & P-value & $\operatorname{Exp}(B)$ & & & & \\
\hline Constant & -2.494 & 0.012 & 0.083 & & & & \\
\hline$T$ & -1.349 & 0.287 & 0.260 & & & & \\
\hline \multirow{2}{*}{ Elemental variables } & Coefficient & \multirow{2}{*}{ P-value } & \multirow{2}{*}{$\operatorname{Exp}\left(B_{2006}\right)$} & Coefficient & \multirow{2}{*}{ P-value } & Coefficient & \multirow{2}{*}{$\operatorname{Exp}\left(B_{2015}\right)$} \\
\hline & $B_{2006}$ & & & $\delta$ & & $B_{2015}$ & \\
\hline$K e T a$ & $-2.078^{\star \star \star}$ & 0.003 & 0.125 & $1.815^{\star \star}$ & 0.015 & -0.263 & 0.769 \\
\hline$K K$ & -0.036 & 0.923 & 0.965 & 0.185 & 0.681 & 0.149 & 1.161 \\
\hline KRM & 0.426 & 0.359 & 1.531 & -0.105 & 0.847 & 0.321 & 1.379 \\
\hline$A G E$ & $0.035^{* *}$ & 0.025 & 1.036 & 0.000 & 0.985 & 0.035 & 1.036 \\
\hline$A H I$ & -0.263 & 0.423 & 0.769 & $0.753^{*}$ & 0.062 & 0.490 & 1.632 \\
\hline$T d F P / B$ & $2.208^{* * *}$ & 0.000 & 9.101 & 0.624 & 0.412 & 2.832 & 16.979 \\
\hline$F a / R e R$ & $-1.916^{* * *}$ & 0.000 & 0.147 & 0.197 & 0.702 & -1.719 & 0.179 \\
\hline FarR & $-3.740 * * *$ & 0.000 & 0.024 & 0.607 & 0.445 & -3.133 & 0.044 \\
\hline$L P$ & 0.114 & 0.550 & 1.121 & -0.341 & 0.119 & -0.227 & 0.797 \\
\hline$R M D$ & -0.036 & 0.844 & 0.965 & -0.300 & 0.189 & -0.336 & 0.715 \\
\hline$R t^{-}$ & $0.540 * * *$ & 0.001 & 1.716 & -0.153 & 0.438 & 0.387 & 1.473 \\
\hline Otfilnto & -0.147 & 0.446 & 0.863 & $0.440^{* *}$ & 0.047 & 0.293 & 1.340 \\
\hline$T W$ & $0.669 * * \star$ & 0.000 & 1.952 & -0.317 & 0.148 & 0.352 & 1.422 \\
\hline Promlnto & 0.134 & 0.425 & 1.143 & -0.106 & 0.587 & 0.028 & 1.028 \\
\hline P-value of Omnivorous Test & \multicolumn{7}{|c|}{$0.000^{* * *}$} \\
\hline Nagelkerke R squared & \multicolumn{7}{|c|}{0.487} \\
\hline
\end{tabular}

Note: * significant at $10 \%, * *$ significant at $5 \%, * * *$ significant at $1 \%$

\footnotetext{
${ }^{5}$ Regarding the detailed introduction of the T-test results, please refer to the subsequent chapter "Test for confirming changes in the
} relative positon of co-ops among other rice retail formats" of the chapter 4 "RESULTS AND DISCUSSION" in Liu et al. (2017). 
Table 5. Highly valued manifestations of co-op members' wants (T-test result)

\begin{tabular}{|c|c|c|c|c|c|c|}
\hline \multirow{2}{*}{$\begin{array}{c}\text { Segments } \\
\text { royal to co-ops }\end{array}$} & \multirow{2}{*}{ Rice-purchasing needs } & \multirow{2}{*}{ Psyehographic eriteria } & \multicolumn{2}{|c|}{ Mean } & \multirow[t]{2}{*}{ T-value } & \multirow{2}{*}{$\begin{array}{c}\text { Mean } \\
\text { difference }\end{array}$} \\
\hline & & & p2006 & ب2015 & & \\
\hline \multirow{6}{*}{ PI seekers } & \multirow{5}{*}{ Trustworthiness need } & Faith in purchase store & 4.26 & 4.16 & -2.027 & $-0.094^{\star}$ \\
\hline & & $\begin{array}{l}\text { Cultivation history information } \\
\text { disclosure }\end{array}$ & 3.41 & 3.44 & 0.545 & 0.031 \\
\hline & & Reputation from other buyers & 3.85 & 3.80 & -1.165 & -0.056 \\
\hline & & Specially cultivated rice & 3.63 & 3.52 & -1.912 & -0.108 \\
\hline & & Good taste & 3.83 & 4.23 & 8.537 & $0.405^{* *}$ \\
\hline & Rinse-free need & Rinse-free & 3.66 & 3.46 & -2.867 & $-0.204^{* *}$ \\
\hline \multirow{11}{*}{ NE seekers } & \multirow{5}{*}{ Official information need } & Rice variety & 3.83 & 3.99 & 1.712 & 0.163 \\
\hline & & Production place & 3.78 & 4.04 & 2.704 & $0.261^{* *}$ \\
\hline & & Brand & 3.63 & 3.67 & 0.293 & 0.035 \\
\hline & & Single species & 4.38 & 3.97 & -3.595 & $-0.409^{* \star \hbar}$ \\
\hline & & Production year & 4.45 & 4.51 & 0.771 & 0.063 \\
\hline & \multirow{5}{*}{ Trustworthiness need } & Faith in purchase store & 4.41 & 4.45 & 0.456 & 0.042 \\
\hline & & $\begin{array}{l}\text { Cultivation history information } \\
\text { disclosure }\end{array}$ & 3.25 & 3.37 & 1.007 & 0.119 \\
\hline & & Reputation from other buyers & 3.68 & 3.57 & -0.967 & -0.112 \\
\hline & & Specially cultivated rice & 3.79 & 3.48 & -2.577 & $-0.311^{\star}$ \\
\hline & & Good taste & 3.94 & 4.49 & 6.135 & $0.553^{* *}$ \\
\hline & Rinse-free need & Rinse-free & 4.38 & 4.31 & -0.715 & -0.072 \\
\hline \multirow{5}{*}{ TW seekers } & \multirow{5}{*}{ Trustworthiness need } & Faith in purchase store & 4.44 & 4.19 & -2.858 & $-0.252^{\star \star *}$ \\
\hline & & $\begin{array}{l}\text { Cultivation history information } \\
\text { disclosure }\end{array}$ & 3.48 & 3.38 & -0.917 & -0.103 \\
\hline & & Reputation from other buyers & 3.66 & 3.54 & -1.121 & -0.118 \\
\hline & & Specially cultivated rice & 3.78 & 3.38 & -3.347 & $-0.398^{* *}$ \\
\hline & & Good taste & 3.90 & 4.34 & 3.936 & $0.440^{\star k}$ \\
\hline
\end{tabular}

Source: Table 10. in Liu et al. (2017)

Note: $*$ significant at $5 \%, * *$ significant at $1 \%$

sion. This point is consistent with the development philosophy of the co-ops, "Aiming at the realization of a new society where trust is spread" as. And accordingly, it can be said that the trust in the co-op is not broken. From now on, it will be essential to continue cultivating trust through communication with co-op members. Moreover, with respect to "trustworthiness need", "good taste" is a specific psychographic criterion that has a great deal of influence on this need, might be an effective incentive. As suggested in Liu et al. (2017), referring to the successful experience of F-Co-op's Rice Center, "the "Rice Taste Test", the definition for which was taken from the Japan Grain Inspection Association (KOKKEN), is a test for the taste of rice through both organoleptic examination and physicochemical analysis; this may be an effective method for ensuring the provision of delicious rice". Meanwhile, how to convey accurate and well-understood information about the results of the "Rice Taste Test" to co-op members is also an important point needs to be considered. In addition, regarding the assortment of rice, it suggests that knowing the exact location of excellent production places is critical for co-op members. Related to the assortment, rinse-free rice, as one determinant especially for "Nonprice elements seekers", during past 10 years still keeps its extremely high evaluation almost without change, revealed that the assortment of rinse-free rice is essential as always. Lastly, there is one point needed to be emphasized that because it was estimated that as the age increases, the frequency of use of co-ops tends to be higher, to develop more spread of home delivery or group buying systems to provide fresher, healthier products to elder co-op members for their convenience can be expected as one sustainable and promising marketing strategy for co-ops' future.

\section{AUTHOR CONTRIBUTION}

Ran LIU, as the lead researcher of this study, identified the research gap and problem statement and is responsible for data collection, analysis and write-up of this paper. All this Ran LIU did under the technical and academic guidance and supervision from her supervisor Susumu FUKUDA and vice-supervisor Masahiro 
MORITAKA who both provided critical comments and suggestions on every stage of the research process and edited different draft versions of this article.

\section{REFERENCES}

Cosslett, S. R., 1981 Efficient estimation of discrete-choice models. In "Structural Analysis of Discrete Data with Economic Applications", ed. By C. F. Manski, and D. McFadden. Cambridge, MA: The MIT Press

Fukuda, S. and Shimizu, C. 2008 A Study on Safety and Security Need of Rice Consumers as Seen from the Household Nonglutinous Rice Purchasing Behavior. In "Economic Analysis of Food Safety and Security", ed. by S. Fukuda, Kyushu Academic Publishing Promotion Center of NPO Inc., Fukuoka, pp.1-26

Fuyuki, K. 2005 Changes in rice consumption and distribution structure and sales strategies. Japanese Journal of Farm Management. 42(4): 42-51

Japan Finance Corporation (JFC). 2011 Result of $1^{\text {st }}$ Consumer Behavior Forecasting Survey in 2011. Retrieved from https:// www.jfc.go.jp/n/findings/pdf/topics_110901_1.pdf

Japanese Consumers' Cooperative Union (JCCU). 2012 Co-op Sanchoku: A Unique Business Practice Developed by the Japanese Consumer Co-operatives. Ed. by Asiedu, I, Y. and Hayashi, K. Retrieved from http://jccu.coop/eng/products/pdf/ coop_sanchoku.pdf

Japanese Consumers' Cooperative Union (JCCU). 2006 Nationwide Co-op Members' Attitude Survey Report 2006.

Japanese Consumers' Cooperative Union (JCCU). 2012 Nationwide Co-op Members' Attitude Survey Report 2012.

Japanese Consumers' Cooperative Union (JCCU). 2015 Nationwide Co-op Members' Attitude Survey Report 2015.

Kado, K. 2007 Chapter 6. The Review of CO-OP Japan. In
"Possibility and Problems of Public Sectors: Current Issues and CO-OP Japan", ed. by Sociology Laboratory in Asahikawa Campus of Hokkaido University of Education, Hokkaido University of Education., Asahikawa, pp. 53-67

Kikuchi, P. and Yamao, M. 2014 Japanese Consumer Cooperative: An Alternative Institutional Model to Promote Organizational Learning for Cooperatives in Thailand. Retrieved from https://www.researchgate.net/profile/ Pornprapa_Sakulsaeng/publication/281274095

Kim, H, S. and Yoon, C, H. 2004 Determinants of subscriber churn and customer loyalty in the Korean mobile telephony market. Telecommunications Policy. 28: 751-765

Kako, T. 2003 Economic Development and Rice Economy. Agricultural economic papers of Kobe University. 36: 109121

Kotler, P. and Armstrong, G. 1999 Marketing: An Introduction (Fourth Edition). Transl. By M. Tsukitani, Pearson Education Press Inc., Japan, pp. 39-76

Liu, R., Moritaka, M. and Fukuda, S. 2017 The Position of Consumer Cooperatives as a Rice Retail Format in Japan: An Analysis of the Fukuoka Prefectural Consumer Cooperative Members' Rice-purchasing Needs and Behaviors. Journal of the Faculty of Agriculture, Kyushu University. 62(1):295308

Ministry of Agriculture, Forestry and Fisheries (MAFF). 2008 Food Self-sufficiency Ratio Report in Fiscal 2006. Retrieved from http://www.maff.go.jp/j/press/kanbo/anpo/pdf/150807_201.pdf

Resano, H., Pérez-Cueto, F.J.A., Sanjuán, A.I., Barcellos, M.D. de ., Grunert, K.G., Verbeke, W. 2011 Consumer satisfaction with dry-cured ham in five European countries. Meat Science. 87: 336-343

[News] Japan's food self-sufficiency rate marks 39 percent for five years in a row. 2015, August 8. The Japan Agricultural News. Retrieved from http://english.agrinews.co.jp/?p=3704 